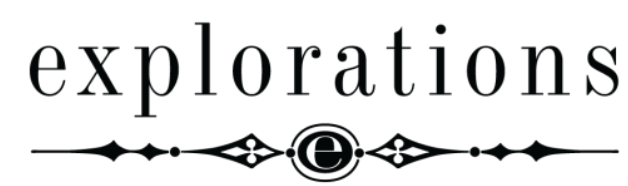

Explorations: A Journal of Language and Literature

\title{
The Broker in Pornography and Violence: Lou Reed in Lulu's World
}

DOI: $10.25167 /$ EXP13.20.8.4

\author{
Sławomir Kuźnicki (University of Opole) \\ ORCID: 0000-0002-8034-9469
}

\begin{abstract}
The article analyses the literary and cultural layers of Lulu, the album published by Lou Reed in collaboration with Metallica, based on Frank Wedekind's two modernist dramas: Earth Spirit (1895) and Pandora's Box (1904). In Reed's reinterpretation, the two plays become his means through which he enters the area of disturbing perversion and graphic pornography. Consequently, Reeds seems to follow Susan Sontag's diagnosis according to which the goal of pornographic literature is to disorient and to disturb mental balance. In the case of Lulu, it demonstrates Reed's strategies of crossing the borders between what is commonly accepted and what is rejected because of its non-normative quality. It results in multilayered kinkiness that outreaches the literary frames of the project and makes it possible to view Lulu as a piece of art that is both uncompromising and visionary.
\end{abstract}

Key words: Lou Reed, Frank Wedekind, Metallica, pornography, violence, shock, transgression

\section{INTRODUCTION: LYRICS WITH MELODIES}

Directly after the publication of Lulu - his collaborative work with Metallica - Lou Reed stated: "I had this dream of the kind of songs you could do with rock, if you looked at it from the point of view of William Burroughs, or Hubert Selby, or Tennessee Williams, for that matter ..., if you could put together lyrics like that, and have a melody with it" (quoted in Shteamer 2011). To a great extent, Lulu is the realization of this dream as its plot is loosely based on Frank Wedekind's two controversial plays of the modernist era: Earth Spirit (1895) and Pandora's Box (1904). Lulu's - the protagonist's - story becomes Reed's portal through which he enters the zone of perverse violence and explicit pornography. He does what is characteristic for his entire oeuvre: referring to the basic instincts of human sexuality, he penetrates the experiences that appear to be the foundations of our culture (although they are frequently marginalized in the mainstream discourse). Another culturally controversial element of his strategy is the decision to

Explorations: A Journal of Language and Literature, 8 (2020), pp. 33-47 
cooperate on this project with Metallica, the band whose rather conservative and preservative music stands in stark contrast to Reed's transgressive artistic activities. The result is a multidimensional kinkiness that outreaches the frames of a literary project, and which makes Lulu an uncompromising, visionary work of art.

\section{All ROADS LEAD TO LULU}

Lulu is neither Reed's first flirt with literature (and its reworking within the frames of rock culture), nor his first foray into the world of graphic pornography and violence. It is even justified to risk the thesis that the images of perverse sexuality constitute the key to understand his entire literary legacy. From the middle of the 1960s to Lulu, an outsider's rage continued to be the leitmotif of his songs in which he kept on focusing on neurotic and emotionally perturbed people. Susan Sontag notes: "Tamed as it may be, sexuality remains one of the demonic forces in human consciousness - pushing us at intervals close to taboo and dangerous desires, which range from the impulse to commit sudden arbitrary violence upon another person to the voluptuous yearning for the extinction of one's consciousness, for death itself' $(1969,57)$. Reed's poetry perfectly fits this recognition: it centers on the descriptions of sex and violence that - according to the rock poet - are not contradictory forces, but supplement each other to create the full universe of human existence. In other words, sex and violence constitute the foundations of our experience. Simultaneously, Reed's understanding of human sexuality can be placed both inside and outside the Christian borders of hierarchical system of sexual value. In this sense, his strategy can be seen as a practical realization of Gayle S. Rubin's assumption that " $\mathrm{t}] \mathrm{he}$ most despised sexual castes currently include transsexuals, transvestites, fetishists, sadomasochists, sex workers such as prostitutes and porn models, and the lowliest of all, those whose eroticism transgresses generational boundaries" $(1984,151)$. Reed's pictures of sexuality bring us closer to some kind of truth: if not about the surrounding world, then at least about us. Such a postulate is always articulated though the independent art that becomes a vessel for this unsettled truth. It parallels Michel Foucault, who notices "the existence in our era of a discourse in which sex, the revelation of truth, the overturning of global laws, the proclamation of a new day to come, and the promise of a certain felicity are linked together" $(1978,7)$.

From the very beginning of his career, Lou Reed attempted to realize this demystification. At least two instances of such an artistic strategy seem significant, and can be viewed as predecessors of Lulu. The first one is "Venus in Furs," the song from The Velvet Underground's debut album The Velvet Underground and Nico released in 1967. Its lyrical layer is the direct reference to Leopold von Sacher-Masoch's scandalous and semi-autobiographical novel Venus in Furs (1870). Sometimes categorized as a novella, the text is part of Love section, the first volume of the never-completed series Legacy of Cain. Following the literary original which is famous for its graphic representations of sadomasochism - the term itself is a combination of von SacherMasoch's and Donatien Alphonse François, Marquis de Sade's names - Reed's lyrics focus on these transgressive practices, mainly bondage. The song begins with the following words:

Shiny, shiny, shiny boots of leather

Whiplash girlchild in the dark. (The Velvet Underground and Nico 1967) 
Then, it features Severin von Kusiemski, the protagonist of the novel, who seeks sexual fulfillment in physical and verbal humiliation. Interestingly, during that time, i.e. the end of the 1960s, Lou Reed was known among his friends and associates as Lulu - a fact that cannot be belittled in the context of the 2011 record.

Another, even more important example of Reed's journeys into the perverse and kinky is his third solo album Berlin from 1973. The record is a pioneering mixture of a concept album and rock opera. In its lyrics, narrated from the perspective of the male protagonist, Reed relates the story of the misfortunate relationship of Caroline and Jim. In "Caroline Says I" the woman accuses him of being a sexual loser:

Caroline says that I'm just a toy

she wants a man, not just a boy. (Reed 1973)

In response, Jim charges her of being a slag and a junkie:

They're taking her children away

Because she was making it with sisters and brothers

And everyone else, all of the others

Like cheap officers who would stand there and flirt in front of me...

And all of the drugs she took, every one, every one. (Reed 1973)

This spiral of incomprehension and incongruity finds its tragic climax in the explicit scenes of domestic violence. "Oh, Jim:"

And when you're filled up to here with hate

Don't you know you gotta get it straight

Filled up to here with hate

Beat her black and blue and get it straight. (Reed 1973)

Finally, Caroline commits suicide, but this fact does not fill Jim with any signs of remorse. In "Sad Song" he declares:

I'm gonna stop wasting time

Somebody else would have broken both of her arms. (Reed 1973)

From the perspective of time it may appear that the plot of Berlin is a contemporary variation on Wedekind's plays, and because of that it might have exerted a significant impact on Reed's decision to reinterpret Lulu's story. It becomes even more probable when one takes into consideration the fact that the first ever staged performances comprising the full cycle of Berlin songs were realized only between 2006 and 2008, i.e. in the period directly preluding Reed's work on Wedekind's dramas. In 1973 such performances could not be realized because of the high costs exceeding both Reed's and RCA Records' financial capabilities. Five concerts from December 2006 were filmed to become Lou Reed's Berlin: Live at St. Ann's Warehouse, directed by Julian Schnabel (2007). There is, then, a dependency between Berlin and Lulu, the latter being the crowning of Reed's artistic paths, the place where his fascinations in sexual perversions, 
transgressive experiences and German literature of the turn of the $19^{\text {th }}$ and $20^{\text {th }}$ century concur.

\section{FRANK WEDEKIND SHOCKS}

Rita Felski notes: "An aesthetic of shock hooks up to all that we find grisly or abhorrent, to warring impulses of desire and disgust, subterranean dramas of psychic anxiety and ambivalence" (2008, 130). Such a definition of shock finds its perfect application in Frank Wedekind's two famous plays. In 1892 the German playwright started working on a play, initially just one titled Lulu: A Monster Tragedy, and which relates the story of a young dancer Lulu and her depravation as well as moral downfall. The fact of her femininity is important here, because - as Rubin notes - "[p]art of the modern ideology of sex is that lust is the province of men, purity that of women. It is no accident that pornography and perversions have been considered part of the male domain" $(1984,170)$. Consequently, Lulu is the archetype of a fallen woman and a victim of men's lust: she "dances her way through German high society in tales involving sex, lies and murder in degrees never before depicted in the theater" (Goldstein 2014). During her childhood and adolescence she is physically abused by her guardian who later forces her to prostitution. As an adult woman, she becomes a notorious lover in Dr Schön's family. Then she continues her life of a sexual victim and femme fatale as the wife of Dr Goll and Schwarz, while still continuing her ambivalent relationships with the Schöns, both the father and the son. Finally, she ends as a prostitute on the streets of London around 1888-1889 and becomes one of Jack the Ripper's victims. Felski comments on shock:

Shock thus marks the antithesis of the blissful enfolding and voluptuous pleasure that we associate with enchantment. Instead of being rocked and cradled, we find ourselves ambushed and under assault; shock invades consciousness and broaches the reader's or viewer's defenses. Smashing into the psyche like a blunt instrument, it can wreak havoc on our usual ways of ordering and understanding the world. Our sense of equilibrium is destroyed; we are left at sea, dazed and confused, fumbling for words, unable to piece together a coherent response. $(2008,113)$

The reaction of Wedekind's contemporaries was similar: the play was highly censored and the author was forced to remove from the text the Jack the Ripper's scene that was considered too violent and, thus, too disturbing. The first part of the projected diptych, supplemented with a more neutral scene taking place in the theatre wardrobe, was published in 1895 as Earth Spirit (Erdgeist). The London fragments, also extended, appeared only in 1902 as Pandora's Box (Die Büchse der Pandora), after a four-year trial when Wedekind and his publisher were forced to defend themselves against the accusations of spreading immoral demeanors.

Lulu constitutes the center around which all the other characters of the two plays orbit. She is a highly ambiguous figure and hence one that evokes anxiety. On the one hand, she is a fallen woman, a victim to the capitalistic system in which a female becomes someone else's belonging, and the terms legalizing this state of affairs are directly connected to the oppressive and patriarchal nature of the institution of marriage. 
She is, then, an object, a toy in the hands of lecherous men driven by their erotic desires. She is - as she declares herself - "a beast ... [that] wishes to be worth biting at" (Wedekind 1918a, 40). Elsewhere, she states: "God grant that I dance the last sparks of intelligence out of their heads" $(1918 \mathrm{a}, 62)$. On the other hand, she can be perceived as a peculiar femme fatale, the woman who uses her features - personal charm, physicality, and ostensible submissiveness - to survive in the man-dominated world. She manipulates them, frequently making them mad and urging them to commit a crime. Although they are not aware of it, it is her who is the motive power. When she says "That was me," finishing Alva's - one of her lover's - words "It's just my fate-“"(1918a, 85), she makes it clear that nothing happens accidentally. As an unrestricted libertine, when asked by Alva whether she loves him, she replies: "I? Not a soul" (1918a, 88). Consequently, she situates herself somewhere beyond the male impact zone. Although a moral victory - if traditionally understood morality is at all the issue here - is hers, in the patriarchal world she has no chance for a decent survival.

One of the goals of modernist literature was to disestablish the division into what is high and what is low. It seems that Wedekind achieved a lot in this field. Not only did he incorporate graphic violence and perverse sexuality into his plays, but he also made the literature he created somehow unliterary. That is why he made those story arcs which are sensational and criminal foundations of the plot; that is why he drew inspiration for his plays from tabloids which were (and still are) full of exaggerated descriptions of violence; finally, that is why he avoided cheap moralizing, additionally discomposing the defenders of conventional and mendacious moral attitudes. This distance to the problem and the protagonist, as well as the conscious will to break the decorum also characterize Lou Reed and his attempt to rewrite the story of Lulu. It seems impossible not to agree with Felski in this broader respect:

Rather than lapsing into a dormant or moribund state after a founding flash of glory, works of art may experience a hectic, even frenetic, afterlife characterized by new convergences and mutating constellations of meaning. Circumventing any desire on our part to relegate them to a hinterland of outdated or regressive beliefs, texts from the past can interrupt our stories of cultural progress, speak across centuries, spark moments of affinity across the gulf of temporal difference. Their very untimeliness renders them newly timely. $(2008,120)$

\section{TO GIVE LULU A ROCK LIFE}

Lou Reed's Lulu is not the first attempt to translate the literary original into a language different from the theatrical one. The first endeavour is Alban Berg's opera Lulu (1937), whose full version completed by Friedrich Cerha premiered in 1979. The movie industry adapted Wedekind's plays three times: as Georg Wilhelm Pabst's acclaimed silent film Pandora's Box (1929), starring Louise Brooks as Lulu; as Lulu, directed in 1962 by Rolf Thiele; and again as Lulu directed by Walerian Borowczyk (1980). In the case of Reed, the idea of a new stage version of Wedekind's dramas came from the American master of avant-garde theatre, Robert Wilson, who asked the rock artist to compose music to his adaptation. The results of this collaboration could be admired in 2011 when the play was staged in Germany, Italy and France. However, 
working on the score, Reed came up with the idea of a more contemporary and much more radical reinterpretation of the literary original. Working on the project with his wife and the avant-garde artist Laurie Anderson, he fully realized how ambitious and difficult it is. Simultaneously, from the very beginning he knew how to achieve his goal. As he recalls: "I have to have Metallica muscle. Sixty miles an hour won't do. It's 110 or nothing" (quoted in Shteamer 2011).

The choice of the heavy metal icon for the accompanying band (the four musicians also contributed to the arrangements of the songs) was shocking. Reed seemed to represent a completely different aesthetics of rock music than Metallica. What is more, in the past he used to express rather negative opinions on the band. ${ }^{1}$ Nonetheless, the five artists decided at least to try to collaborate. After a joint performance during the Rock and Roll Hall of Fame concert in October 2009 (they played Reed's two songs from The Velvet Underground's repertoire: "Sweet Jane" and "White Light / White Heat"), in 2011 they started working on a new record. Initially, the album was to contain Reed's old songs recorded anew, but this quickly changed: Reed suggested creating music to the poems in which he retells Lulu's story. Published in October 2011, Lulu is the result of this surprising and controversial cooperation.

The controversies, which seemed unavoidable at the very early stage of the collaboration, erupted the moment the album was published. First of all, they stemmed from the validity of the cooperation between the transgressive Reed who does not hesitate to undertake difficult and kinky themes in his art and the band representing the world of conservative rock/metal music. Consequently, Metallica's fans and the classic rock critics received Lulu most poorly: at Metacritic, which assigns a normalized rating out of one hundred to reviews from mainstream critics, the album received an average score of forty-five, based on thirty-one reviews. On the other hand, Laurie Anderson assumes that David Bowie was one of the biggest admirers of the record: "after Lou's death, David Bowie made a big point of saying to me, 'Listen, this is Lou's greatest work. This is his masterpiece. Just wait, it will be like Berlin. It will take everyone a while to catch up"" (quoted in Beaumont-Thomas 2015). Unfortunately, the negative views dominated (they still do), which made the musicians abandon the plans of presenting the material onstage. There is no doubt that these exponential and extreme reactions to the album are triggered not by the music, but rather by its lyrical layer and the fact that the deprived and depriving Lulu speaks here with the voice of a sixty-nine-year-old man. Susan Sontag makes the following note on the repellent nature of true art and the uncompromising attitude of an artist:

Being a freelance explorer of spiritual dangers, the artist gains a certain license to behave differently from other people; matching the singularity of his vocation, he may be decked out with a suitably eccentric life style, or he may not. His job is inventing trophies of his experiences - objects and gestures that fascinate and enthrall, not merely (as prescribed by older notions of the artist) edify or entertain. His principal means of fascinating is to advance one step further in the dialectic of outrage. He

${ }^{1}$ However, in 2011 Reed stated sarcastically: "I've loved Metallica since I was a kid" (quoted in Shteamer 2011). 
seeks to make his work repulsive, obscure, inaccessible; in short, to give what is, or seems to be, not wanted. $(1969,45)$

Reed is such an artist on Lulu. By his last - as it soon transpired - piece of art he achieved what he was wishing to do all his career, i.e. not to leave anyone indifferent to it.

It also applies to the artwork of the record designed by David Turner of the international design firm Turner Duckworth, earlier known for his Grammy Award-winning packaging for Metallica's album Death Magnetic from 2008. Lulu's front cover features Stan Musilk's photograph of the genuine, run-down early $20^{\text {th }}$-century tailor's dummy. David Turner explains the concept in the following way:

The main character was broken in many ways, and exhibited behavior both human and heartless. We found the mannequin featured in the packaging at the Museum der Dinge in Berlin. It felt appropriate both for the mood and the era of the plays. Once we showed her image to the band and Lou, everyone felt we had found our Lulu.

We were inspired by the music and the ideas within the lyrics, and we collaborated closely with Lou and Metallica, with them approving all our work. However, it was also a very personal project, because unlike most of the projects we work on which are highly commercial in nature, this was an opportunity to create images as art, for the sheer pleasure of creative exploration, because that was the driving force behind the music. (quoted in Goldstein 2014)

What is emblematic of the image is both the artifice of the photographed object and its almost human characteristics. The figure's visible imperfections - scratches, slivers, the letters stylized as if written with blood - correspond with Lulu and her story. Turner states: "The packaging design reflected Lulu's delicate balance of humanity and 'soullessness' by melding the female form - shot live in-studio - with that of a period-appropriate mannequin" (quoted in Goldstein 2014). Consequently, the entire design - honored with a "Gold Award for CD/DVD Packaging" in the 2013 Graphis Annual - evokes some unnamed anxiety and the feeling of uneasiness, both of which match Reed's view on the uncompromising nature of art.

\section{I AM THE TRUTH, THE BEAUTY}

According to Sontag, "[t]he exemplary modern artist is a broker in madness" (1969, 45). In the case of Lou Reed, this definition requires extending the assortment offered by him to include pornography and violence. These two phenomena constitute the basis for Lulu's story that Reed relates throughout eight out of ten songs on the album. ${ }^{2}$ The protagonist is introduced in "Brandenburg Gate" which, at the same time becomes the

\footnotetext{
${ }^{2}$ The two songs thematically unrelated to the plot of Lulu are: "Little Dog" dedicated to Lolabelle, Anderson's and Reed's terrier that died a few months before the beginning of the project (in 2015 Anderson directed the movie Heart of a Dog, a poetic epitaph to both her husband and her dog), and "Junior Dad" with the lyrics written a couple of years earlier about Reed's difficult relations with his late father.
} 
overture to the main history. The song begins quietly and intimately from the sounds of the acoustic guitar and Reed's voice. Metallica joins a while later, inspissating the song, but not breaking entirely its carefully built atmosphere. The track continues this way: heavy but calm wall of sound, with James Hetfield's additional vocals, provides a safe counterpoint for Reed's story in which Lulu presents herself as a simple, provincial girl, who dreams in her mundane and boring existence about something more: the lights of fame, the thrill of emotions, the passionate love, the dissolution in the colours of life:

I'm just a small town girl who wants to give it a whirl

While my looks still hold me straight

Straight up to illusion and fantasy's fusion

Of reality mixed with drink. (Reed and Metallica 2011)

Lulu quickly notices her chance for adventure and transgression, i.e. in the second song on the album, "The View." Selected for the only single promoting the album - and accompanied by the video clip directed by Darren Aronofsky - the song instantly attacks with the massive guitar riff. The listener can get the impression that they are thrown into the ritual whirlpool of sounds. The music is simple, raw and explicit. It rolls like a bulldozer that once speeds up (again Hetfield provides his vocals here), and the other time slows down, until it reaches its intensive and multilayered ending. In this song Lulu declares: "I am a chorus of the voices" (Reed and Metallica 2011), emphasizing her complex and ambiguous identity. This is her rite of passage from the previous state of an ordinary, dormant girl into a self-conscious woman who is aware of the drives that, once hidden, now transpire. It can be seen in the following excerpts from the song uttered by her:

I attract you and repel you...

There is no time for guilt or second guessing,

second guessing based on feeling...

I want to see your suicide

I want to see you give it up...

Pain and evil have their place

Sitting here beside me. (Reed and Metallica 2011)

Sontag states: "It's well known that when people venture into the far reaches of consciousness, they do so at the peril of their sanity. But the 'human scale' or humanistic standard proper to ordinary life and conduct seems misplaced when applied to art. It oversimplifies" (1969, 44-45). Similarly, Lulu becomes her own creation, her own perverse piece of art (or a piece of perverse art):

I am the truth, the beauty

that causes you to cross your sacred boundaries. (Reed and Metallica 2011)

Parodying the two finishing lines of "Ode on a Grecian Urn" -

"Beauty is truth, truth beauty," - that is all

Ye know on earth, and all ye need to know (Keats 1899, 135) 
- Reed establishes a completely new aesthetic horizon, which can parallel Foucault's following assessment: "Sexual ethics requires, still and always, that the individual conform to a certain art of living which defines the aesthetic and ethical criteria of existence" (Foucault 1986, 67). Lulu situates herself on the side of both art and life, truth and beauty, morality and perversion - all of these at once, without evaluating and hierarchization, without recognizing and following the rules. The heroine confesses impertinently:

I am the root

I am the progress

I am the aggressor. (Reed and Metallica 2011)

She belongs now to risk and darkness.

The next track - "Pumping Blood" - brings this darkness of "supreme violation" (Reed and Metallica 2011). After a short introduction built around disturbing sounds produced by string instruments, the song is taken over by the brutal and ritual drum loop, to some extent evoking the rhythm of a heartbeat suggested by the title. Lars Urlich's drum section is the basis of the entire song, regardless of the music slowing down - leaving almost empty space for Reed's voice and Kirk Hammett's drilling guitar - or haring away, helter-skelter, towards heavy metal pandemonium, towards perdition. The lyrics are directly inspired by the Jack the Ripper's scene from Wedekind's Pandora's Box. Before murdering the protagonist, the London serial killer tells her: "You'll never get away from me again," and after the deed he murmurs to himself: "That was a piece of work!" (Wedekind 1918b, 79). This is the moment in the story when - as Rita Felski notes - "violence in the text bleeds into the violence of the text: the wielding of words as weapons to intensify and amplify its aesthetics of shock" $(2008,128)$. Reed's Lulu takes a more active role in this act - languishing on the edge, she seems to encourage her torturer:

Would you rip and cut me?

Use a knife on me, be shocked at the boldness

The coldness of this little heart tied up in leather?

Would you take the measure of the blood that I pump

In the manic confusion of love? (Reed and Metallica 2011)

She finds this illusion of love in kinky and instant violence that is symbolized by Jack the Ripper. One may assume that she begs him not for mercy, but to give her even greater pain so that she could lose herself in this anguish totally and permanently. The poem perfectly demonstrates Reed's strategy of crossing borders between what is commonly accepted and what is rejected due to its non-normative character. It parallels Rubin's idea that "[t]he sexual system is not a monolithic, omnipotent structure" $(1984,161)$. The new norm-anti-norm proposed by Reed is a sexual experience that outreaches standard behaviors, an experience that is - figuratively speaking - bathed in blood, just as these words:

Blood in the foyer, the bathroom, the tea room,

The kitchen, with her knives splayed. (Reed and Metallica 2011) 
As Foucault states in reference to de Sade's equally transgressive sexual practices:

... sex is without any norm or intrinsic rule that might be formulated from its own nature; but it is subject to the unrestricted law of a power which itself knows no other law but its own; if by chance it is at times forced to accept the order of progressions carefully disciplined into successive days, this exercise carries it to a point where it is no longer anything but a unique and naked sovereignty: an unlimited right of all-powerful monstrosity. (1978, 149)

\section{THE MARRIAGE OF EROS AND THANATOS}

The story continues with "Mistress Dread," which elaborates the rush signaled in "Pumping Blood" in a full and uncompromised way. The music races, giving no single moment of rest. It becomes the spiral that draws us into it; it is a cold-blooded murderer who violates our bodies; it is chaos that no one can escape from. In the lyrics Lulu confesses:

I'm a woman who likes men

But this is something else. (Reed and Metallica 2011)

This unnamed feeling that grows inside of her is a desire to be humiliated and self-destructed: a death wish. Foucault states: "Sex is worth dying for. It is in this (strictly historical) sense that sex is indeed imbued with the death instinct" $(1978,156)$. Lulu expresses this amalgam of sex and death in the fantasies of being tied, beaten, kicked, spat at, strangled, bleeding. She wants to be brutally raped to experience her physicality in the most extreme way and, by this, to achieve some higher level of freedom. She says to the man who dominates her: "Open and release me" (Reed and Metallica 2011). Doing so, she openly opposes the traditionally understood norms of sexuality, according to which "... some sex acts are considered to be so intrinsically vile that no one should be allowed under any circumstance to perform them. The fact that individuals consent to or even prefer them is taken to be additional evidence of depravity" (Rubin 1984, 159). At the same time, she calls herself both Mistress Dread and Goliath, which suggests a multidimensional character of their relationship. Foucault notes: “... sexual activity was located within the broad parameters of life and death, of time, becoming, and eternity. It became necessary because the individual was fated to die, and in order that he might in a sense escape death" (1990, 135).

"Mistress Dread" can be read as the apogee of Lulu's story of becoming anew; the track that follows - "Iced Honey" - pictures the result of this transformation. From the musical point of view, it is the most accessible fragment of the album, a far echo of the melodics characteristic of David Bowie and Lou Reed's classic Transformer (1972), co-written and coproduced by the British artist. The song is motoric, but also relatively light, dulcet and surprisingly easy (no wonder there were plans - eventually dropped - to release it as the second single form the album). From the chaos of the rite of passage as painted in "Mistress Dread," in "Iced Honey" Lulu appears to be altered, stronger. As the title suggests, she is ice-cold, although she does not stop provoking. She plays the role of an "iced honey," but in fact she is a unique and beautiful butterfly. She challenges the 
surrounding world saying "You can't put a butterfly in a jar" (Reed and Metallica 2011), to finish her train of thought with the following punchline:

No matter what you say, no matter what you do

A butterfly heart flies right past you

There's nothing to say, nothing to do

See if the ice will melt for you. (Reed and Metallica 2011)

Lulu's conviction about her singularity and power symbolizes the victory of her sexuality over death, or mixing these two elements together. Even if this victory was purely illusionary, even if this symbiosis was temporary and fragile. Sontag notes: "For the most part, the figures who play the role of sexual objects in pornography are made of the same stuff as one principal 'humour' of comedy" (1969, 53-54). Lulu inevitably moves closer to such a comic quality. Simultaneously, however, she does not drift away from the tragedy that constitutes who she really is.

On the contrary, Lulu's existence is filled with fundamental questions, as exemplified in "Cheat on Me." Musically, the song is a masterpiece in the art of creating suspense. It gradually emerges from the buzzes and dimness, and accrues with every second, every beat, every word. Enhanced by the string quartet, the music meanders in the direction of disturbing chaos. Further sounds - second voice, guitar drones, and mounting up rhythm section - join and the atmosphere inspissates: with time, the song drifts towards almost unbearable intensity that one cannot resist. The same applies to the litany of inquiries that appear in the text, and which suggest some sort of existential distraction. Lulu keeps on asking:

Why do you cheat on me?

Why do I cheat on thee?

Why do I cheat on me? (Reed and Metallica 2011)

They mark the trap in which the heroine finds herself. Lulu flounces between a life full of strong feelings -

I have a passionate heart

It can tear us apart,

and a complete emotional sterilization -

Your love means zero to me

I'm a passionateless wave upon the sea. (Reed and Metallica 2011)

Self-awareness that she achieves through the sexual experience is shaky and frail. Foucault notes:

It is through sex - in fact, an imaginary point determined by the deployment of sexuality - that each individual has to pass in order to have access to his own intelligibility (seeing that it is both the hidden aspect and the generative principle of meaning), to the whole of his body (since it is a real and threatened part of it, while 
symbolically constituting the whole), to his identity (since it joins the force of a drive to the singularity of a history). (1978, 155-156)

In the case of Lulu, the results and consequences of self-establishing are more painful than the process itself.

\section{HER NAME IS NEMESIS}

The next track on the record pictures the moment frustration and fury are born. Musically, "Frustration" is closest to Metallica's typical heavy metal sound. Although the disturbing introduction with the muezzin-like chant may not herald it, the song's massive guitar riff smashes everything that comes across. In the middle, there happen the excerpts somehow deconstructing the heavy metal character of the entire composition: slowdowns followed by sudden accelerations, the calm contrasted by the avant-garde guitar zings, and then again the already-mentioned motorial riff. Lyrically, this is the moment Lulu turns from a fallen and submissive woman into a dominating figure: sexual fetishes enable her to become a man. She confesses: "You're feeling less like a whore but you stimulate" (Reed and Metallica 2011). Pretending is a kind of a game, but it is also a possibility to learn the other side. Equipped with an artificial penis - this symbol of patriarchal power - Lulu seems determined:

To be dead to have no feeling

To be dry and spermless like a girl

I want so much to hurt you

Marry me, I want you as my wife. (Reed and Metallica 2011)

She enters the part of a misogynic man so profoundly that she even loses herself in it, simultaneously annihilating a woman inside of her. However, this is also a game: in kinky sexuality, as well as in role-playing that pornographic imagination triggers. Sontag characterizes the latter in the following way: "The universe proposed by the pornographic imagination is a total universe. It has the power to ingest and metamorphose and translate all concerns that are fed into it, reducing everything into the one negotiable currency of the erotic imperative. All action is conceived of as a set of sexual exchanges" $(1969,66)$. Lulu becomes such a creature: on the wings of rage, she glides towards her - ostensibly - unknown destiny.

Commenting on the literary contents of Lulu after Reed's death in 2013, Laurie Anderson stated: "I've been reading the lyrics and it is so fierce. It's written by a man who understood fear and rage and venom and terror and revenge and love. And it is raging" (quoted in Beaumont-Thomas 2015). "Dragon," the song finishing Lulu's story illustrates this deluge of fury in the best way. The song is Lulu in a nutshell. It begins with Reed's voice on the background of electric guitar scrapings. But it is just an introduction to the song that actually starts with the incisive guitar riff - probably the best on the entire album - adequately strengthened by the rhythm section. Perseverant motility does not let itself a moment of stoppage, and the song swells till the listener can - or maybe should - lose themselves in it. It describes the last act of the theatre of atrocity: 
I'm clawing your chest till your collarbone bleeds

Piercing your nipples till I bite them off

I scratch your face and bite your shoulders. (Reed and Metallica 2011)

At the same time, Lulu splits her personality into the one of a victim, and the one of an aggressor, which is emphasized by the narrative shift from the first into the third person singular. Her body remains human and naturalistically physical; she is a hybrid:

The hair on your shoulders

The smell of your armpit

The taste of your vulva. (Reed and Metallica 2011)

She is the object "one fucks with" and as such is deprived of any meaning. Consequently, she is no longer there:

You don't actually care

Love for you is no beginning

You're not really there

Hallucination. (Reed and Metallica 2011)

Like the eponymous dragon, Lulu becomes a being that does not exist and exists at the same time; she functions beyond time and space. Sontag observes: "Man, the sick animal, bears within him an appetite which can drive him mad. Such is the understanding of sexuality - as something beyond good and evil, beyond love, beyond sanity; as a resource for ordeal and for breaking through the limits of consciousness" $(1969,58)$. Now she has all the cards and: she plays the role of the goddess of revenge who decides about others' fate. Similarly to a caterpillar pupating into a butterfly, from a sexual object Lulu mutates into a cold statute that remains silent.

\section{CONCLUSIONS: NOT AN ORDINARY HEART}

Susan Sontag considers "pornography [as] one of the branches of literature - science fiction is another - aiming at disorientation, at psychic dislocation" $(1969,47)$. To some extent, this is the result that Reed manages to achieve. The artist states: “... what I see myself as is a writer. Whether I'm a nice guy, whether I'm a liar, whether I'm immoral should have nothing to do with it" (quoted in Fong-Torres 2013). He functions outside the borders of morality and traditionally understood arts, no matter if one applies this to literature or rock culture. Paul Goodman notes: 'If a work is felt to be 'experimental,' it is not that the writer is doing something new but that he is making an effort to be different, to be not traditional" $(2011,193)$. Reed succeeds in this as well: linking sex and violence, he creates a multi-generic piece of art that one cannot simply ignore; a work that is annoying and beautiful, blemished and concentrated, bohemian and situated as close to real life as possible, unmitigated. Sontag notes:

What makes a work of pornography part of the history of art. Rather than of trash is not distance, the superimposition of a consciousness more conformable to that of 
ordinary reality upon the "deranged consciousness" of the erotically obsessed. Rather, it is the originality, thoroughness, authenticity, and power of that deranged consciousness itself, as incarnated in a work. From the point of view of art, the exclusivity of consciousness embodied in pornographic books is in itself neither anomalous nor anti-literary. $(1969,47)$

However, somewhere deep inside this abyss of pornography and violence, there is hidden at least a trace of devouring melancholy. Consequently, Lulu speaking with Lou Reed's voice - or Lou Reed hiding behind Lulu's mask - should have the last word: "In the end it was an ordinary heart" (Reed and Metallica 2011).

\section{REFERENCES}

Beaumont-Thomas, Ben. 2015. "David Bowie: Lou Reed's Masterpiece is Metallica Collaboration Lulu." TheGuardian.com, April 20. Accessed May 17, 2019. https://www.theguardian.com/music/2015/apr/20/david-bowie-lou-reed-masterpiecemetallica-lulu.

Felski, Rita. 2008. Uses of Literature. Malden: Blackwell Publishing.

Fong-Torres, Ben. 2013. "Lou Reed as Remembered by Legendary Rock Journalist Ben Fong-Torres." Hollywoodreporter.com, November 30. Accessed May 17, 2019. https://www.hollywoodreporter.com/news/lou-reed-as-remembered-by-651659.

Foucault, Michel. 1978. History of Sexuality. Volume 1: An Introduction. Translated by Robert Hurley. New York: Pantheon Books.

Foucault, Michel. 1986. The Care of the Self. Volume 3 of the History of Sexuality. Translated by Robert Hurley. New York: Pantheon Books.

Foucault, Michel. 1990. The Use of Pleasure. Volume 2 of the History of Sexuality. Translated by Robert Hurley. New York: Vintage Books.

Goldstein, Mike. 2014. "Interview with David Turner - The Making of the Lulu Album Cover." AlbumCoverHallofFame.com, January 10. Accessed May 17, 2019. https://albumcoverhalloffame.wordpress.com/2014/01/10/interview-with-davidturner-the-making-of-the-lulu-album-cover/.

Goodman, Paul. 2011. "Format and Communication." In The Paul Goodman Reader, edited by Taylor Stoehr, 183-198. Oakland: PM Press.

Keats, John. 1899. The Complete Poetical Works and Letters of John Keats. Boston:Houghton, Mifflin and Company.

Reed, Lou. 1973. Berlin. New York: RCA Records.

Reed, Lou and Metallica. 2011. Lulu. Burbank: Warner Bros. Records.

Rubin, Gayle S. 1984. "Thinking Sex: Notes for a Radical Theory of the Politics of Sexuality." In From Gender to Sexuality, 143-178. http://sites.middlebury.edu/sexandsociety/files/2015/01/Rubin-Thinking-Sex.pdf.

Sontag, Susan. 1969. “The Pornographic Imagination.” In Styles of Radical Will, 35-73. New York: Farrar, Straus and Giroux.

Shteamer, Hank. 2011. "The Survivors: Lou Reed and Metallica.” GQ.com, October, 21. Accessed May 17, 2019. https://www.gq.com/story/lou-reed-metallica-gq-musicissue. 
The Velvet Underground and Nico. 1967. The Velvet Underground and Nico. Santa Monica: Verve Records.

Wedekind, Frank. 1918a. Erdgeist (Earth-Spirit): A Tragedy in Four Acts. Translated by Samuel Atkins Eliot, Jr. New York: Boni and Liveright.

Wedekind, Frank. 1918b. Pandora's Box: A Tragedy in Three Acts. Translated by Samuel Atkins Eliot. Jr. New York: Boni and Liveright.

This work is licensed under the Creative Commons Attribution 3.0 Unported License.

$\mathrm{http}: / /$ creativecommons.org/licenses/by/3.0/

AUTHOR'S BIO: Sławomir Kuźnicki, PhD, works as an Assistant Professor at the Institute of Literatures, University of Opole. His academic interests cover utopian, dystopian, speculative, and science fiction, as well as rock studies, i.e. the literary and cultural contexts of rock music. He is the author of Margaret Atwood's Dystopian Fiction: Fire Is Being Eaten (2017), as well as numerous articles in the academic fields mentioned above. He is also a poet with four published volumes of poems in Polish (e.g. Contours in 2018).

E-MAIL: slavekkk@wp.pl 